\title{
Transcatheter closure of patent foramen ovale with the use of the transseptal puncture
}

Nieoperacyjne zamknięcie drożnego otworu owalnego z dostępu przez nakłucie przegrody międzyprzedsionkowej

\author{
Cezary Kępka ${ }^{1}$, Witold Rużyłło ${ }^{1}$, Marcin Demkow ${ }^{1}$, Marek Konka² \\ ${ }^{1}$ Klinika Choroby Wieńcowej i Strukturalnych Chorób Serca, Instytut Kardiologii, Warszawa \\ 2 Pracownia Echokardiografii, Instytut Kardiologii, Warszawa
}

Post Kardiol Interw 2010; 6, 3 (21): 138-141 DOI: $10.5114 /$ pwki.2010.16356

\section{Streszczenie}

Nieoperacyjne zamknięcie drożnego otworu owalnego jest jednym z rutynowych zabiegów w kardiologii interwencyjnej. Jednak u niektórych pacjentów nietypowy, tunelowaty kształt przewodu może uniemożliwić sforsowanie przegrody międzyprzedsionkowej a tym samym wykonanie zabiegu. W pracy opisujemy nietypowy sposób implantacji okludera przez nakłucie przegrody międzyprzedsionkowej. Metoda ta wymaga stałego monitorowania przy pomocy echokardiografii oraz dużego doświadczenia operatorów.

Słowa kluczowe: drożny otwór owalny, nieoperacyjne zamknięcie, nakłucie przegrody międzyprzedsionkowej

\section{Abstract}

Transcatheter patent foramen ovale closure became one of the routinely performed procedure in clinical practice. Despite this, in some patients, due to unfavorable anatomy and tunnel-like foramen passing through the interatrial septum with diagnostic catheter cannot be possible. In this report we present the case of successful implantation of Amplatzer PFO Occluder with the use of transseptal puncture technique.

Key words: patent foramen ovale, transcatheter closure, transseptal technique

\section{Opis przypadku}

Mężczyzna 55-letni, po przebytym udarze niedokrwiennym móżdżku, został skierowany do Instytutu Kardiologii w celu kwalifikacji do leczenia zabiegowego. Na podstawie wcześniej wykonanych badań diagnostycznych wykluczono wtórne przyczyny udaru oraz stwierdzono przeciek na poziomie przegrody międzyprzedsionkowej w badaniu echograficznym. Ostatecznie rozpoznano udar o nieustalonej etiologii (tzw. udar kryptogenny). W ramach prewencji wtórnej pacjentowi zaproponowano zabieg uszczelnienia przegrody międzyprzedsionkowej. W przezklatkowym badaniu echograficznym zwracała uwagę nietypowa anatomia otworu owalnego, zdecydowano więc o konieczności wykonania badania przezprzełykowego przed ostateczną kwalifikacją do zabiegu.

\section{Diagnostyka echokardiograficzna} i technika zabiegu

W celu oceny anatomii ubytku oraz oceny występowania i istotności przecieku wykonano przezprzełykowe badanie echograficzne w warunkach spoczynkowych oraz W czasie próby Valsalvy. W badaniu tym stwierdzono bardzo wiotką przegrodę międzyprzedsionkową oraz nietypowy, tunelowaty ubytek typu drożnego otworu owalnego (ang. patent foramen ovale, PFO) (ryc. 1.). Zastosowanie oceny dopplerowskiej potwierdziło przeciek w okolicy „załamania" przegrody, nie stwierdzono natomiast przecieku w końcowej części tunelu (ryc. 2.). Istotność przecieku (przechodzenie dużej ilości pęcherzyków „kontrastu”) udokumentowano w czasie próby Valsalvy (ryc. 3. A, B). Pacjenta zakwalifikowano do zabiegu uszczelnienia przegrody za pomocą okludera Amplatza.

Adres do korespondencji/Corresponding author:

dr n. med. Cezary Kępka, Klinika Choroby Wieńcowej i Strukturalnych Chorób Serca, Instytut Kardiologii, ul. Alpejska 42, 04-628 Warszawa, tel.: +48 2281540 14, e-mail: c.kepka@ikard.pl

Praca wpłynęła: 2.08.2010, przyjęta do druku 21.08.2010. 
Z dostępu od prawej żyły udowej, za pomocą cewnika diagnostycznego i prowadnika podejmowano wielokrotne, nieskuteczne próby sforsowania przegrody (do implantacji okludera konieczne jest wprowadzenie koszulki naczyniowej przez ubytek do lewego przedsionka). Każdorazowo koniec cewnika diagnostycznego ulegał przemieszczeniu do końcowej części tunelu (ryc. 4.). Ostatecznie po ponownej ocenie anatomii przegrody i ubytku zaplanowano implantację urządzenia przez jatrogennie wytworzony otwór w przegrodzie międzyprzedsionkowej, w okolicy ist- niejącego ubytku. Pod kontrolą echokardiografii przezprzełykowej wykonano skuteczny zabieg nakłucia przegrody od strony prawego przedsionka (ryc. 5. A, B). Przez wytworzony ubytek implantowano okluder Amplatza (Amplatzer PFO Occluder) $25 \mathrm{~mm}$. Przed uwolnieniem urządzenia zweryfikowano jego lokalizację oraz potwierdzono eliminację przecieku. Niewielka zmiana położenia okludera związana z jego uwolnieniem (zjawisko normalne przy zabiegach wykonywanych tą techniką) nie wpłynęła na zmianę szczelności przegrody (ryc. 6.). Zabieg uznano za

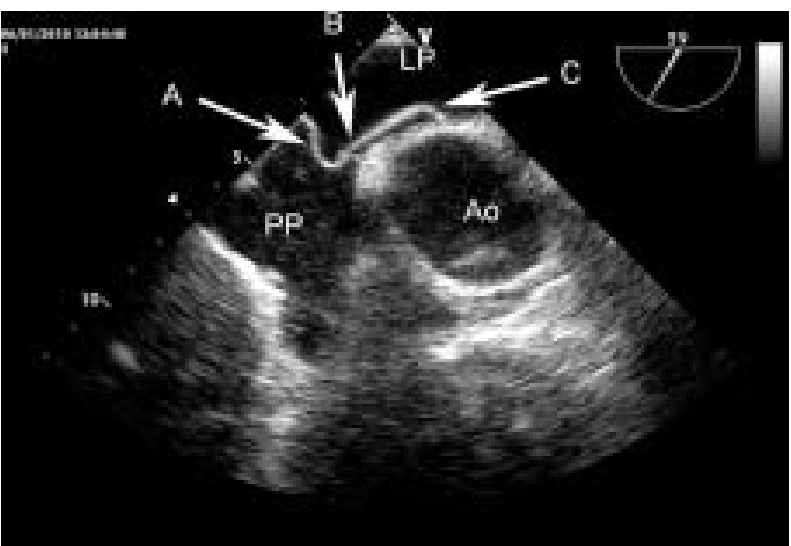

Ryc. 1. Przezprzełykowe badanie echograficzne. Widoczna wiotka, tętniakowata przegroda międzyprzedsionkowa z drożnym, tunelowatym otworem owalnym

A - tętniak przegrody, B - miejsce przecieku, C - tunel wytworzony przez przegrodę, LP - lewy przedsionek, PP - prawy przedsionek, Ao - aorta

Fig. 1. Transoesophageal echocardiography. Floppy, aneurysmal septum with tunnel-like patent foramen ovale can be seen

$A$ - septal aneurysm, $B$ - site of the shunt, $C$-tunnel-like foramen ovale, $L P$ - left atrium, $P P$ - right atrium, Ao - aorta
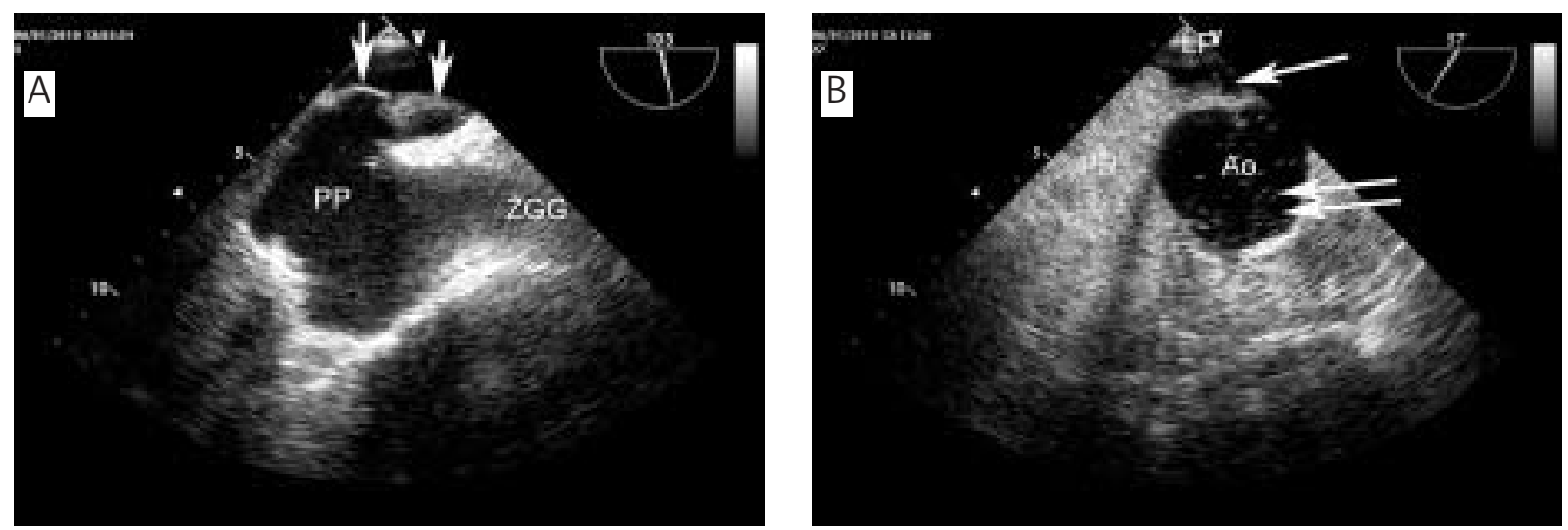

Ryc. 3. Przezprzełykowe badanie echograficzne, akwizycja w czasie próby Valsalvy (wiotka przegroda uwypuklona w stronę lewego przedsionka). Widoczne przechodzenie pęcherzyków „kontrastu” do lewego przedsionka (A) oraz w późniejszej fazie pęcherzyki w aorcie (B) PP - prawy przedsionek, ŻGG - żyła główna górna, Ao - aorta

Fig. 3. Transoesophageal echocardiography. Vasalva maneuver. Significant right-to-left shunt can be seen $(\boldsymbol{A})$, the "bubbles" of contrast in aorta few seconds later (B) $P P$ - right atrium, $\dot{Z} G G$ - superior vena cava, Ao - aorta

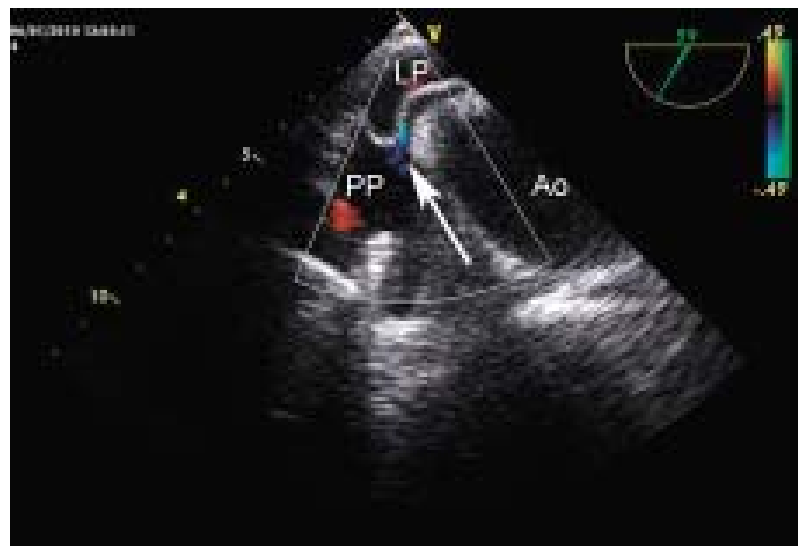

Ryc. 2. Przezprzełykowe badanie echograficzne z zastosowaniem kolorowego dopplera - widoczny przepływ przez przegrodę (strzałka) LP - lewy przedsionek, PP - prawy przedsionek, Ao - aorta

Fig. 2. Transoesophageal echocardiography with color flow mapping - right-to-left shunt via foramen ovale can be seen $L P$ - left atrium, $P P$ - right atrium, Ao-aorta 


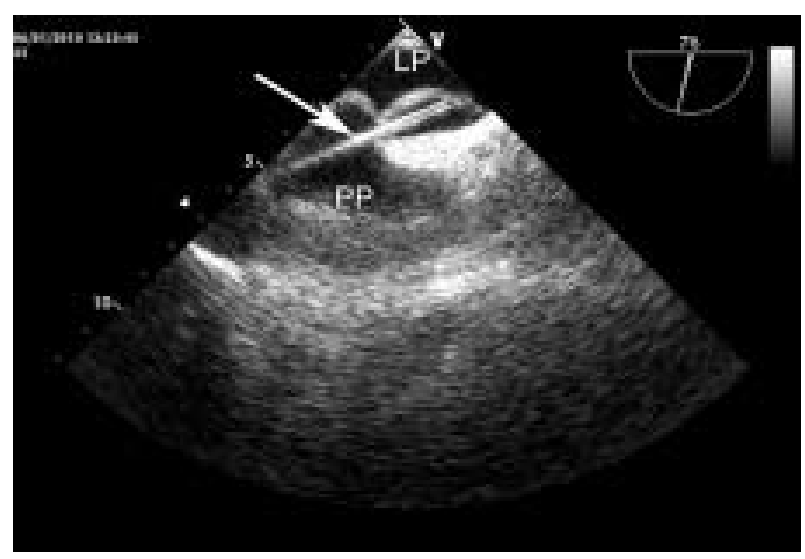

Ryc. 4. Przezprzełykowe badanie echograficzne w czasie próby przejścia cewnikiem z lewego do prawego przedsionka. Widoczny cewnik umieszczony w tunelu wytworzonym przez przegrodę - brak możliwości przejścia do LP

LP - lewy przedsionek, PP - prawy przedsionek

Fig. 4. Transoesophageal echocardiography. Unsuccessful attempt to cross the septum with diagnostic multipurpose catheter. The tip of the catheter located in the tunnel $L P$ - left atrium, $P P$ - right atrium

skuteczny, a pacjentowi zalecono standardową farmakoterapię. W kontrolnym badaniu po upływie miesiąca od zabiegu okluder znajdował się w prawidłowej pozycji, a przegroda pozostawała szczelna.

\section{Omówienie}

W ciągu ostatnich kilku lat nieoperacyjne zamykanie PFO u chorych po przebytych kryptogennych incydentach neurologicznych stało się postępowaniem niemalże rutynowym. W zdecydowanej większości przypadków, przy odpowiednim doświadczeniu operatorów jest to metoda bezpieczna i skuteczna [1]. Niemniej duża różnorodność anatomiczna przegrody międzyprzedsionkowej, jak również otworu owalnego powoduje, że u niektórych pacjentów zabieg taki może być czasochłonny, bardziej ryzykowny i nie zakończyć się sukcesem. Przyczynami nieskuteczności zabiegu mogą być m.in.: brak możliwości przeprowadzenia instrumentarium przez otwór owalny lub implantacja okludera w pozycji, która nie eliminuje przecieku. Powyższe problemy mogą wystąpić szczególnie przy nietypowej anatomii ubytku [2].

Nawet w przypadku bardzo doświadczonych operatorów (ponad 500 zabiegów wykonanych tą techniką) przeprowadzenie cewnika przez otwór owalny przy jego niesprzyjającej anatomii może być niemożliwe. Sytuacja taka miała miejsce w opisanym wyżej przypadku, gdy ubytek miał kształt długiego tunelu, a przeciek rejestrowano w miejscu odległym od anatomicznego końca tunelu. W tej sytuacji uszczelnienie przegrody było możliwe jedynie poprzez wytworzenie jatrogennego otworu w sąsiedztwie PFO, a następnie implantację okludera poprzez ten otwór. Sposób ten w opisanym przypadku okazał się skuteczny i bezpieczny.

Nakłucie przegrody międzyprzedsionkowej może się wiązać z niebezpieczeństwem spowodowania tamponady bądź uszkodzenia struktur wewnątrzsercowych sięgającym 1-2\% [3]. Zabieg ten powinien być wykonywany przez doświadczonego operatora, najlepiej pod kontrolą echokardiografii przezprzełykowej. W opisanym przez nas przypadku możliwość ciągłego monitorowania echokardiograficznego była niezbędna dla skutecznego wykonania zabiegu. Echokardiografia przezprzełykowa umożliwiła nie tylko bezpieczne nakłucie przegrody międzyprzedsionkowej (minimalizacja ryzyka powikłań), ale również pozwoliła na precyzyjną ocenę miejsca nakłucia, co gwarantuje implantację okludera w miejscu pozwalającym na eliminację przecieku przez PFO.

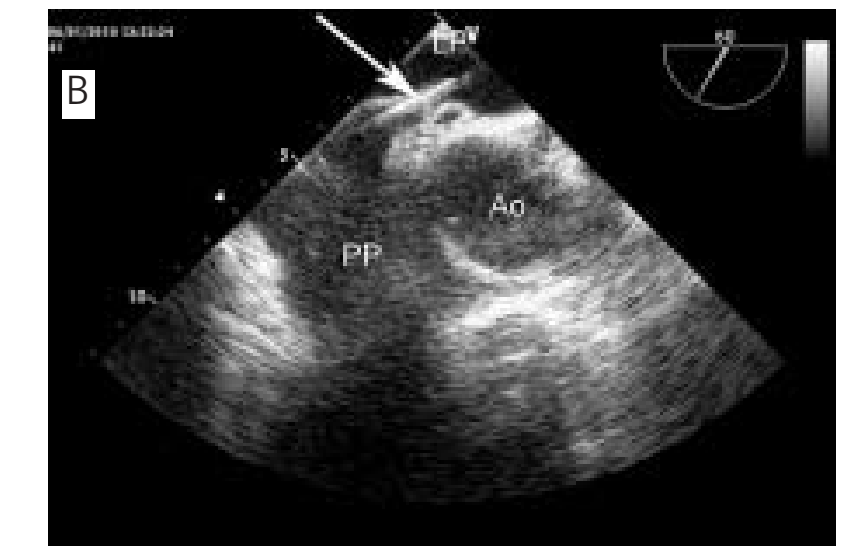

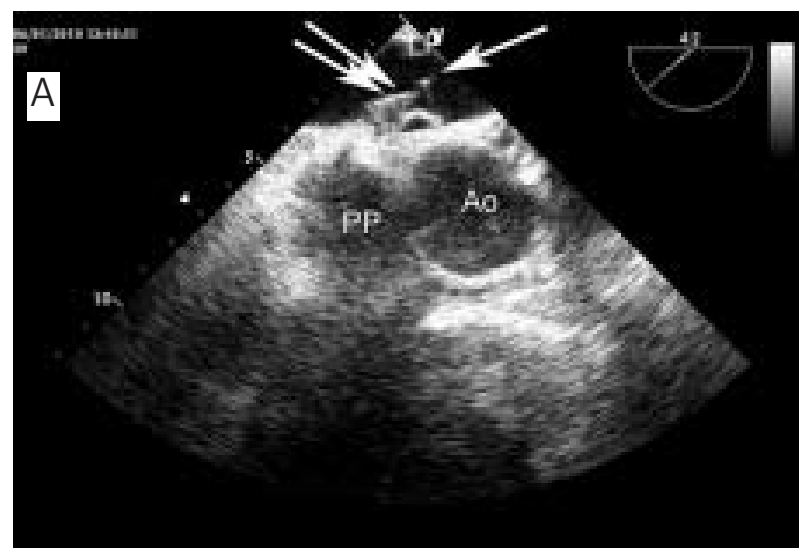

Ryc. 5. Przezprzełykowe badanie echograficzne w czasie nakłuwania przegrody międzyprzedsionkowej. A - igła napinająca przegrodę w okolicach przecieku (dwie strzałki); B - koniec igły w lewym przedsionku LP - lewy przedsionek, PP - prawy przedsionek, Ao - aorta

Fig. 5. Transoesophageal echocardiography. Puncture of the interatrial septum. $A$ - stretching of the septum by the transseptal needle (two arrows); $B$ - tip of the catheter in the left atrium $L P$ - left atrium, $P P$ - right atrium, Ao - aotra 


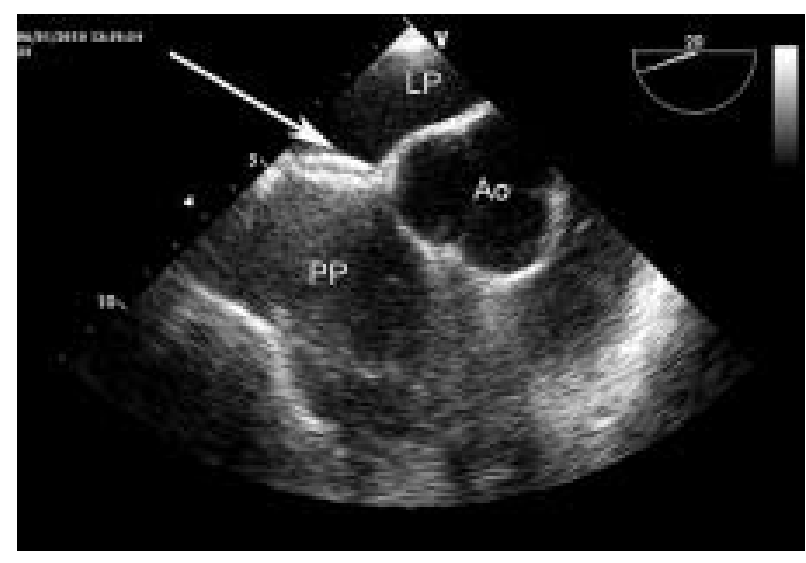

Ryc. 6. Przezprzełykowe badanie echograficzne, końcowy efekt zabiegu. Prawidłowo umieszczony okluder całkowicie eliminuje przeciek. Widoczne wyraźne modelowanie przegrody

LP - lewy przedsionek, PP - prawy przedsionek, Ao - aorta

Fig. 6. Transoesophageal echocardiography. Final effect of the procedure. The shunt is eliminated by occluder implanted into septum

$L P$ - left atrium, $P P$ - right atrium, Ao - aorta

Kolejne zagrożenie dotyczy nieszczelności przegrody pomimo implantacji okludera. Sytuacja taka jest niekorzystna dla pacjenta, gdyż nie eliminuje ryzyka wystąpienia kolejnego epizodu neurologicznego, a więc zabiegu takiego nie można uznać za skuteczny. W literaturze znajdujemy pojedyncze publikacje, które potwierdzają, że skuteczność eliminacji przecieku może być istotnie mniejsza w przypadku implantacji okludera przez nakłucie trans- septalne w porównaniu z implantacją przez natywne PFO $[1,4,5]$. Szczególnie ważne jest więc potwierdzenie eliminacji przecieku przed uwolnieniem urządzenia.

\section{Podsumowanie}

Opisany przypadek pokazuje, że u pacjenta z nietypowym, tunelowatym PFO próba przeprowadzenia cewnika przez ubytek w przegrodzie międzyprzedsionkowej może być nieskuteczna. Alternatywnym sposobem jest implantacja okludera przez nakłucie przegrody międzyprzedsionkowej. Przy kwalifikacji pacjenta do tego typu zabiegu należy pamiętać o możliwych powikłaniach, z których najistotniejszym jest tamponada serca, oraz o prawdopodobnie mniejszej skuteczności tej procedury w eliminacji przecieku.

\section{Piśmiennictwo}

1. Egred M, Andron M, Albouaini K i wsp. Percutaneous closure of patent foramen ovale and atrial septal defect: procedure outcome and medium-term follow-up. J Interv Cardiol 2007; 20: 395-401.

2. Tande AJ, Knickelbine T, Chavez I i wsp. Transseptal technique of percutaneous PFO closure results in persistent interatrial shunting. Catheter Cardiovasc Interv 2005; 65: 295-300.

3. Zaker-Shahrak R, Fuhrer J, Meier B. Transseptal puncture for catheter ablation of atrial fibrillation after device closure of patent foramen ovale. Catheter Cardiovasc Interv 2008; 71: 551-552.

4. Braun MU, Ehrhard K, Strasser RH, Haass M. Occlusion by catheter intervention in patent foramen ovale via additional transseptal puncture. Z Kardiol 2002; 91: 659-662.

5. Chatterjee T, Petzsch M, Ince H i wsp. Interventional closure with Amplatzer PFO occluder of patent foramen ovale in patients with paradoxical cerebral embolism. J Interv Cardiol 2005; 18: 173-179. 